\title{
Terminology and Legislation referring to Percutaneous Facet Procedures to Treat Low Back Pain in Brazil - Current Status
}

\section{Terminologia e legislação referentes aos procedimentos percutâneos facetários para tratamento da lombalgia no Brasil - Estado atual}

\author{
Andrei Fernandes Joaquim ${ }^{1,6}$ Jeronimo Buzetti Milano $2,6\left(\right.$ Jefferson Walter Daniel ${ }^{3,6(1)}$
}

Marcelo Luis Mudo 4,6 Ricardo Vieira Botelho ${ }^{5,6(0)}$

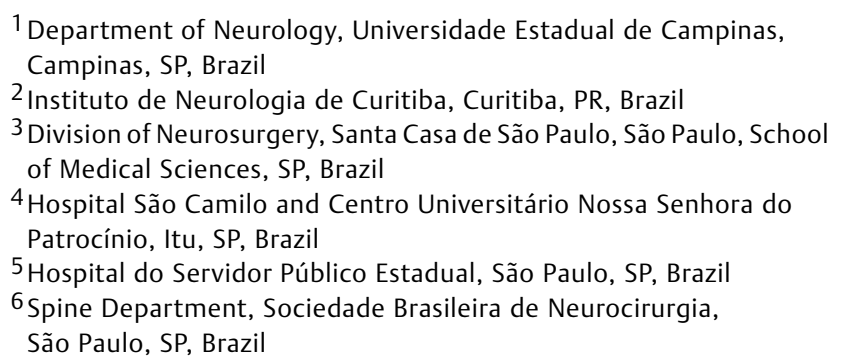

Address for correspondence Andrei Fernandes Joaquim, Department of Neurology, Universidade Estadual de Campinas (Unicamp), Campinas, SP, Brazil (e-mail: andjoaquim@yahoo.com).

Arq Bras Neurocir 2020;39(4):289-293.

\section{Abstract \\ Keywords \\ - percutaneous procedures \\ - denervation \\ - facetary \\ - facet joints \\ - terminology \\ - legislation}

\section{Resumo}

Incongruities in the terminology and in the Brazilian legislation about percutaneous facet procedures (PFPs) for the treatment of chronic lower back pain are frequently the subject of litigations between health professionals and supplementary healthcare providers. The Brazilian Hierarchical Classification of Medical Procedures (CBHPM, in the Portuguese acronym) describes four types of PFPs, while the Brazilian Unified Supplementary Health Terminology (TUSS, in the Portuguese acronym) describes five distinct lumbar PFPs, which correlate with the ones described on the List of Procedures and Events in Health, created by the Brazilian National Agency of Supplementary Health (ANS, in the Portuguese acronym). In the present paper, we review the terminology of the procedures, proposing the unification of the terminology and the abolition of redundancies in the tables. Finally, we developed a single terminology proposal for the PFPs based on their complexity and objectives to be used for the treatment of lower back pain.

As incongruências na terminologia e na legislação brasileira sobre os procedimentos percutâneos facetários (PPFs) para tratamento da dor lombar crônica são constantemente motivos de litígios entre profissionais de saúde e operadoras de saúde suplementar. A Classificação Brasileira Hierarquizada de Procedimentos Médicos received

September 29, 2017

accepted

October 17, 2017
DOI https://doi.org/ 10.1055/s-0037-1608908. ISSN 0103-5355.
Copyright (@) 2020 by Thieme Revinter

Publicações Ltda, Rio de Janeiro, Brazil
License terms

(c) $(1) \$$ 

Palavras-chave
- procedimentos percutâneos
- denervação
- facetária
- facetas
- terminologia
- legislação

(CBHPM) descreve quatro tipos de PPFs, enquanto a Terminologia Unificada de Saúde Suplementar (TUSS) descreve cinco PPFs lombares distintos, os quais se correlacionam com o os tipos listados no Rol de Procedimentos e Eventos em Saúde, elaborado pela Agência Nacional de Saúde Suplementar (ANS). No presente artigo, revisamos a terminologia dos procedimentos, propondo a unificação da terminologia e a abolição de redundâncias nas tabelas. Elaboramos, por fim, uma proposta de terminologia única dos PPFs usados para tratamento da dor lombar baseada em sua complexidade e objetivos.

\section{Introduction}

Lower back pain is one of the most frequent disorders affecting the population, with $\sim$ between 60 and $80 \%$ of people presenting at least one episode of pain. ${ }^{1}$ The treatment is often complex, with an important economic and social impact. In between 15 and $45 \%$ of the cases, some authors believe that low back pain has a larger component originating from lumbar facets (or zygapophyseal joints). ${ }^{2,3}$ Among the main characteristics of the lumbar pain with facet origin, in addition to the pain in the lumbar region itself, there is also an increase in pain intensity with spine extension; irradiation of the pain to the posterior region of the thigh but not below the knees, pain on palpation of posterior spine elements and response to pain control with injection of perifaceted local anesthetics or in the medial dorsal branch region. ${ }^{2,3}$ Based on this physiopathological concept, surgical procedures for cutaneous blocking (temporary or definitive) of the pain impulse from the facets have been used in the diagnosis (such as therapeutic tests) or in the treatment of the so-called facet pain. ${ }^{4,5}$

The present article aims to discuss the Brazilian terminology and legislation regarding the faceted percutaneous procedures for the treatment of lumbar pain, since the theme is constantly the target of disputes between health practitioners.

\section{Definitions and Terms}

The term "rhizotomy" is often used in the description of the percutaneous treatment of facet pain. "Rizo" refers to the roots, while "Tomy" means section or "Cut." The term rhizotomy is often used as a synonym to "neurotomy," a term that refers to the section or cut of a nerve or nervous root. The term denervation seems to be more appropriate, since it means depriving an area of a specific nerve, but not necessarily cutting it, being, thus, more appropriate.

Rhizotomies are used for the treatment of various neurosurgical diseases, such as selective dorsal rhizotomy (SDR), used for the treatment of spasticity, especially in patients with severe spastic diparesis or diplegia of limbs (usually related to cerebral palsy). ${ }^{6,7}$ There are also rhizotomies for treating trigeminal neuralgia, performed with alcohol or phenol (chemical rhizomes), with a balloon (mechanical rhizotomy) or radiofrequency, for the destruction of sensory fibers and symptoms relief. ${ }^{6,7}$
However, the present article focuses on the rhizotomies made in the spine for pain treatment. Since the targets of the injury or anesthetic blockade are the nervous branches and not the roots, the term rhizotomy seems incorrect, so the term used from now on is denervation. In the lumbar spine, rhizotomies are used to damage the dorsal-medial branches of the spinal nerves, with the aim of damaging the sensory fibers that cause back pain related to the factional syndrome. ${ }^{2,4}$ They can be chemically performed, usually with local anesthetic and corticosteroids, or with radiofrequency injury, where an electrical current will result in selective neural injury. In general, two or three levels should be injured so that the facets are denervated, since innervation is generally multisegmental. ${ }^{2,4}$

\section{Current Legislation}

The Brazilian Hierarchized Classification of Medical Procedures (CBHPM, in the Portuguese acronym) constitutes the parameter of medical payments that aims to ensure the adequate and balanced remuneration of the medical services provided. ${ }^{8}$ It was a result of a joint action between the Brazilian Physician Association (AMB, in the Portuguese acronym), the Federal Council of Medicine (CFM, in the Portuguese acronym) and medical specialty societies. The CBHPM is the responsibility of AMB, which is also responsible for the inclusion of new items in the table.

There are four different forms of facetary percutaneous procedures described in the CBHPM ( - Table 1). ${ }^{8}$

The unified terminology of supplementary health (TUSS, in the Portuguese acronym), in which the codes and nomenclatures of the medical procedures are standardized in harmony with the information of private health, determined by the information exchange in supplementary health (TISS, in the Portuguese acronym), was created by the National Supplementary Health Agency (ANS, in the Portuguese acronym), and its use has become mandatory since $2010 .^{9}$ It is based on the CBHPM $5^{\text {th }}$ edition. The TUSS is not a price table, but a terminological reference, and in it five distinct lumbar faceted percutaneous procedures are described.

The Rol de Procedimentos Médicos e Eventos em Saúde (list of medical procedures and health events) is the list of procedures, exams and treatments with mandatory coverage by health plans. ${ }^{10}$ It should be noted that this is the minimum coverage the health plans should offer, it is valid for plans with 
Table 1 Description of facet percutaneous procedures according to the Brazilian Medical Association 2016 Brazilian Hierarchical Classification of Medical Procedures

\begin{tabular}{|l|l|l|l|l|}
\hline Procedure & Code & $\begin{array}{l}\text { Operacional } \\
\text { cost - size }\end{array}$ & $\begin{array}{l}\text { Auxiliaries } \\
\text { number }\end{array}$ & $\begin{array}{l}\text { Anesthetic } \\
\text { size }\end{array}$ \\
\hline Percutaneuos rhizotomy per segment - any method & $3.14 .03 .33-6$ & $10 \mathrm{C}$ & 01 & 5 \\
\hline Articular facet percutaneous denervation per segment & $3.14 .03 .03-4$ & $9 \mathrm{C}$ & 01 & 4 \\
\hline Paraspinal facet block & $3.16 .02 .12-6$ & $4 \mathrm{C}$ & 0 & 3 \\
\hline Spine: foraminal , facet or articular infiltration & $4.08 .13 .35-5$ & $5 \mathrm{~A}$ & 0 & 5 \\
\hline
\end{tabular}

contracts beginning after the $1^{\text {st }}$ of January 1999, and it is revised every 2 years. The $1^{\text {st }}$ list was published in 1998 , and it was updated in 2001, 2004, 2008, 2010, 2011 and 2013. The current list, updated in January 2, 2016, includes 21 new procedures, such as laboratory exams and oral medication for cancer treatment, as well as the expansion of consultations with speech therapists, nutritionists, physical therapists and psychotherapists. ${ }^{10}$ Currently, in the health plans contracted after January 2,1999, the minimum coverage of health plans is defined by the CBHPM and TUSS tables and the list of procedures and events in health. There are also four forms of lumbar faceted percutaneous procedures described in it.

The ANS elaborated a table with the correlation between the items in the list of procedures and health events and the corresponding terms in the TUSS (- Table 2 ). ${ }^{9}$

Considering that the procedures are not detailed, there are no scientific criteria for differentiating them. Terminologies can be used, in our opinion, to refer to the procedure performed in a chemical or radiofrequency manner.

In the ANS 2016 list, there are four different procedures, one of which is percutaneous rhizotomy with or without radiofrequency, with a guideline of use (DUT, in portuguese acronym). ${ }^{10,11}$ The following four procedures are described:

1. Percutaneous denervation of articular facet - Group: Central and peripheral nervous system; Subgroup: Peripheral nerves.
2. Paraspinal facet block - Group: Other invasive procedures; Subgroup: Anesthetic nerve blocks and neurovascular stimuli.

3. Vertebral column: Foraminal, facet or articular infiltration - Group: Diagnostic methods per image; Subgroup: Interventional and therapeutical diagnostic methods by image.

4. Percutaneous rhizotomy with or without radiofrequency (with DUT) - Group: Central and peripheral nervous system; Subgroup: Peripheral nerves. To use this procedure, see DUT number $62 .{ }^{11}$ In it, percutaneous rhizotomy with or without radiofrequency has the following criteria for use:

4.1 Mandatory coverage for patients with facet pain (lumbago, back pain or cervicalgia), when all the criteria of group I and none of the criteria of group II are fulfilled:

\section{Group I}

(a) Limitation of activities of daily living (ADLs) for at least 6 weeks;

(b) Reduction $>50 \%$ of the reported pain measured by the visual analogue scale (VAS) after facet infiltration using local anesthetic;

(c) Failure in the appropriate conservative treatment.

Table 2 Correlation table between the unified supplementary health terminology (see 1.0.2) and the list of procedures and events in health of the National Agency for Supplementary Health (RN n 262/2011 altered by RN N 281/2011)

\begin{tabular}{|l|l|l|l|}
\hline TUSS code & Group - Subgroup - TUSS & Procedure TUSS & $\begin{array}{l}\text { ANS list (RN n. 262/2011 altered } \\
\text { by RN n. 281/2011) }\end{array}$ \\
\hline 40813363 & $\begin{array}{l}\text { Diagnostic and therapeutical } \\
\text { procedures - interventional methods }\end{array}$ & $\begin{array}{l}\text { Spine: foraminal, facet or } \\
\text { articular infiltration }\end{array}$ & $\begin{array}{l}\text { Extra-articular diagnnostic or } \\
\text { therapeutical punction /artrocentesis } \\
\text { (infiltration/dry needling): } \\
\text { imaging-oriented or not }\end{array}$ \\
\hline 31403034 & $\begin{array}{l}\text { Invasive surgical procedures - } \\
\text { central and peripheric nervous system }\end{array}$ & $\begin{array}{l}\text { Articular facet percutaneous } \\
\text { denervation per segment }\end{array}$ & $\begin{array}{l}\text { Articular facet percutaneous } \\
\text { denervation }\end{array}$ \\
\hline 31403336 & $\begin{array}{l}\text { Invasive surgical procedures - } \\
\text { central and peripheric nervous system }\end{array}$ & $\begin{array}{l}\text { Percutaneuos rhizotomy } \\
\text { per segment - any method }\end{array}$ & Percutaneuos rhizotomy \\
\hline 31602126 & $\begin{array}{l}\text { Invasive surgical procedures - } \\
\text { other procedures }\end{array}$ & Paraspinal facet block & Paraspinal facet block \\
\hline 30715423 & $\begin{array}{l}\text { Invasive surgical procedures - } \\
\text { musculoskeletal system }\end{array}$ & Radiculotomy & Percutaneuos rhizotomy \\
\hline
\end{tabular}

Abbreviations: ANS, National Agency for Supplementary Health; TUSS, unified supplementary health terminology 


\section{Group II}

(a) Previous spinal surgery in the analyzed segment;

(b) Disc herniation;

(c) Signs of surgical stenosis or potential instability.

4.2 Mandatory coverage for patients with focal and intense spasticity with disabling symptoms, even after the completion of medical and treatment with a physical therapist.

4.3 Patients with trigeminal, glossopharyngeal, occipital or intermediate nerve neuralgia, refractory or intolerant to continuous clinical treatment for at least 3 months.

As an important consideration, the DUT 62 published in the ANS list does not specify the form of rhizotomy (with or without radiofrequency) for which it applies. Thus, the technical opinion published in August 2015 by the Brazilian Column Society (SBC, in the Portuguese acronym), disputes the ANS's DUT. ${ }^{12}$ The requests from SBC for DUT change are summarized below:

Request n. 1: Define that this DUT applies only to cases in which the radiofrequency method is used, and does not apply to percutaneous chemical rhizotomy. Reason: The DUTwas proposed to guide the percutaneous radiofrequency rhizotomy, not the chemical procedure, which became systematically denied by the carriers, in many cases, based on the DUT. Thus, the DUT should not be used for periradicular or facet infiltrations (or percutaneous rhizotomies by chemical method)

Request n. 2: Removal of group II, which cites the exclusion criteria for the procedure.

\section{Reasons}

- Previous surgery in another segment is not contraindication for the performance of the radiofrequency rhizotomy;

- Herniated discs are not contraindications to facet rhizotomies, because the degenerative disc process can occur simultaneously in the articular facets.

- Cases of lumbar stenosis can be beneficiated by rhizotomies when the lumbar pain component is more exuberant.

Request n. 3: Inclusion of the considerations elaborated by the Brazilian Society of Neurosurgery (SBN, in the Portuguese acronym) related to the use of radiofrequency in treating spinal diseases, published in June 2014.

Reason: In document SBN-89/2014,13 The SBN elaborates a document directed to the health plans carriers due to the constant denials they gave to patents for facet and periradicular infiltrations, based on DUT 62. In the document, SBN clarifies that the DUT of the ANS refers exclusively to radiofrequency rhizotomies, and cannot be extrapolated to facet or periradicular infiltrations. Moreover, it proposes that radiofrequency rhizotomy should have higher fees than those of infiltrations, since it requires a longer time of radiological exposure, knowledge and management of technological resources and locational tests that precede the ablation. Finally, they emphasize that the DUT does not contemplate the exceptions, already exposed above in the SBC document.
The document concludes with the consideration that the tomography or radioscopy-guided infiltrations correspond, in technical terms, to percutaneous rhizotomy by chemical agents and, therefore, it should be charged the same as the CBHPM code 3.14.03.33.6 (Percutaneous rhizotomy by any method per segment $-10 \mathrm{C}$ ).

\section{Discussion}

Firstly, lack of definition for the terminology leads to different types of interpretations, which can make health plan carriers classify interventions as small size procedures, despite their technical characteristics, to decrease the compensation paid to health professionals. In our interpretation, considering the previous exposure, where the "rhizotomy" or "radiculotomy" corresponds to the section of nerves, we believe that the term "denervation" should be used preferentially. The terms rhizotomy and radiculotomy would not be used for percutaneous procedures in the spine, be they with local anesthetic, any other chemical method or even radiofrequency.

Moreover, according to the SBN-89/2014 evaluation and the attached justification, percutaneous radiofrequency denervation should be considered more complex than chemical denervation. $^{13}$

The facet blockade with local anesthetic, necessary for the diagnosis of facet syndrome and a prerequisite for the use of radiofrequency, requires the same technical nuances as the facet denervation by chemical method, therefore they can be under a single code, since it represents the same procedure.

In this way, hierarchically, there would be the definition of two procedures:

1. Percutaneous denervation by chemical method (including diagnostic facet block with local anesthetic) by segment

2. Radiofrequency percutaneous denervation - with revision of the DUT 62, according to the suggestion of the SBN and the SBC, by segment.

Even more so, although the operational size is similar, it is essential to separate the foraminal (epidural) infiltrations from the facet ones, since they have distinct clinical indications as well as different complication profiles. Epidural infiltrations could be described, as follows, in three groups:

1. foraminal steroids and/or local anesthetic infiltration per segment

2. interlaminar steroids and/or local anesthetics infiltration per segment

3. caudal steroids and/or local anesthetics infiltration

\section{Conclusions}

Terminology unification and the abolition of redundancies in the tables, referring to the same procedures with different hierarchizations, are fundamental to reduce litigations between physicians and health carriers. In addition, it allows better future scientific studies, both evaluating the effectiveness of the methods and cost. In the present article, we present a proposal of a single terminology and hierarchization of the facet percutaneous procedures used for the treatment of lumbar pain. 


\section{Conflicts of Interests}

The authors declare that there are no conflicts of interests.

\section{References}

1 Deyo RA, Weinstein JN. Low back pain. N Engl J Med 2001;344 (05):363-370

2 Schwarzer AC, Derby R, Aprill CN, Fortin J, Kine G, Bogduk N. Pain from the lumbar zygapophysial joints: a test of two models. J Spinal Disord 1994;7(04):331-336

3 Manchikanti L, Pampati V, Fellows B, Bakhit CE. Prevalence of lumbar facet joint pain in chronic low back pain. Pain Physician 1999;2(03):59-64

4 Filippiadis DK, Kelekis A. A review of percutaneous techniques for low back pain and neuralgia: current trends in epidural infiltrations, intervertebral disk and facet joint therapies. $\mathrm{Br} \mathrm{J}$ Radiol 2016;89(1057):20150357

5 Manchikanti L, Pampati V, Singh V, Falco FJ. Assessment of the escalating growth of facet joint interventions in the medicare population in the United States from 2000 to 2011. Pain Physician 2013;16(04):E365-E378

6 Eller JL, Raslan AM, Burchiel KJ. Trigeminal neuralgia: definition and classification. Neurosurg Focus 2005;18(05):E3

7 Abou Al-Shaar H, Imtiaz MT, Alhalabi H, Alsubaie SM, Sabbagh AJ. Selective dorsal rhizotomy: A multidisciplinary approach to treating spastic diplegia. Asian J Neurosurg 2017;12(03):454-465

8 Associação Médica Brasileira. CBHPM - 2016-Classificação Brasileira Hierarquizada de Procedimentos Médicos - Associação
Médica Brasileira. Disponível em: http://amb.org.br/_arquivos/_ arquivos/_downloads/CBHPM-2016.pdf. Accesed in 2017 (Sept. 12)

9 Agência Nacional de Saúde Complementar. Tabela de Correlação entre a terminologia unificada da Saúde Suplementar (ver 1.0.2) e o Rol de Procedimentos e Eventos em Saúde (RN n 262/2011 alterada pela RN n 281/2011). Disponível em: http://www. ans">http://www.ans.gov.br/images/stories/Plano_de_saude_e_Operadoras/Area_do_-consumidor/tabela_de_correlacao_de_termologias.pdf. Acessado em: 2017 (Set. 12)

10 Agência Nacional de Saúde Complementar. Rol de Procedimentos e eventos e Saúde 2016-Anexo I - Agência Nacional de Saúde Suplementar. Disponível em: http://www.ans.gov.br/images/stories/Plano _de_saude_e_Operadoras/Area_do_consumidor/rol/rol 2016_diretrizes_utilizacao.pdf Acessado em: 2017 (Set. 12)

11 Agência Nacional de Saúde Complementar. Rol de Procedimentos e eventos e Saúde 2016-Anexo II - Agência Nacional de Saúde Suplementar. Disponível em: http://www.ans.gov.br/images/stories/Plano _de_saude_e_Operadoras/Area_do_consumidor/rol/ROL2016_listagem_procedimentos.pdf Acessado em: 2017(Set 12)

12 Sociedade Brasileira de Coluna. Solicitação de revisão de diretriz de utilização (DUT) para o procedimento 'Rizotomia percutânea com ou sem radiofrequência' Parecer da Sociedade Brasileira de Coluna. Disponível em: http://www.coluna.com.br/imagens/pdf/parecertec_revisaodutrizotomia_v150930.pdf Acessado em: 2017 (Set 12)

13 Artigo disponível em formato eletrônico. Parecer da Sociedade Brasileira de Neurocirurgia SBN 89-2014. Disponível em: http:// www.sbn.com.br/upload/user/files/89-Relatorio_Operadoras_Planos_Saude.pdf. Acessado em: 2017 (Sept 12) 